\title{
CHINESE STATE CAPITALISM AND WESTERN ANTITRUST POLICY
}

\author{
Nicolas Petit*
}

\section{Introduction}

Enthused by China's conversion to the free market system in 1978 and its adoption of Western-style market institutions, the world has spent the last few decades turning a blind eye to China's real "governance" problem: that a shadow Party-State system permeates all branches of the economy. ${ }^{1}$ Whatever Washington-consensus style institutions are put in place, whatever State Owned Enterprise ("SOE") reform is introduced, corporate and market governance occur under the rule of the Chinese Communist Party ("CCP"). And the CCP's guidebook is the Leninist command that the whole of society shall be run as "single countrywide State syndicate". ${ }^{2}$

This paper contends that China's syndicated economic organization creates conditions that are conducive to antitrust problems and to which the Western world must awaken. Of course, a conventional antitrust eye will immediately make the case that low-priced Chinese imports have introduced intense competition into Western markets. But those positive surges of competition coincide with two negative predicaments. First, worrying parallels can be drawn between the conduct of Chinese firms and the maladies that led the US Congress to adopt antitrust rules in the late XIXth century: rampant industry coordination, rapacious M\&A, and the perversion of democratic institutions. Chinese firms collectively can be considered to constitute a "supertrust" of a kind that Rockefeller and Carnegie would have recognized, indeed envied. Second, the unrestricted operation of the CCP in Western markets - together with the unilateral protection of its home market - sap Western societies' trust in competitive markets. The point here is not that there is an "unlevel playing field" between Western and Chinese investors. ${ }^{3}$ Instead, the point is that our elites' silent acceptance of the CCP-led syndicate as a global business partner may deal a lethal blow to already damaged public confidence in the free competition and free trade agenda. These two concerns, and in particular the latter, compel an antitrust awakening in the Western world.

The West has not identified this problem to date, trusting that indigenous market governance institutions modeled on international best practices would cure those (infantile) diseases. A Chinese domestic antitrust law was adopted in 2007 and State agencies were given drastic enforcement powers. ${ }^{4}$ Since 2009, discussions have taken place in international circles on the distortions of competition caused by Chinese State Owned Enterprises ("SOEs") and on the

\footnotetext{
* Professor of Law, University of Liege (ULg), Liege Competition and Innovation Institute ("LCII"). Nicolas.petit@ulg.ac.be. This paper has benefited from the support of the American Security Project, www.americansecurityproject.org.

${ }^{1}$ David Shambaugh, China's Future, Polity Press, 2016, talking of a "fashionable analytical zeitgeist of the day within China-watching circles", Preface, xv.

${ }^{2}$ Lenin, Collected Works, Chapter V, p. 478.

${ }^{3}$ For evidence of the unlevel playing field, see David Dollar, "China as a Global Investor", Asia Working Group, Paper 4, Brookings Institution; New York Times, Xi Jinping Hears Tough Complaints of American Business, September 23, 2015, Jane Perlez \& Nick Wingfield.

${ }^{4}$ This entered into force on August 1, 2008: Anti-Monopoly Law of the People's Republic of China, [2008] Presidential Order No. 68, August 30, 2007.
} 
necessity of competitive neutrality. ${ }^{5}$ Across the world, delegation, forbearance and optimism have guided the Western world's policy vis-a-vis China.

This policy stance is no longer tenable. The CCP/SOE problem calls for urgent remediation by the US and the EU. First, because the ongoing mega-wave of Chinese M\&A on global markets risks placing the CCP in command of sizeable Western assets. ${ }^{6}$ Much like a Trojan horse, China's Leninist economic governance is infiltrating the daily lives of Western consumers, producers and workers.

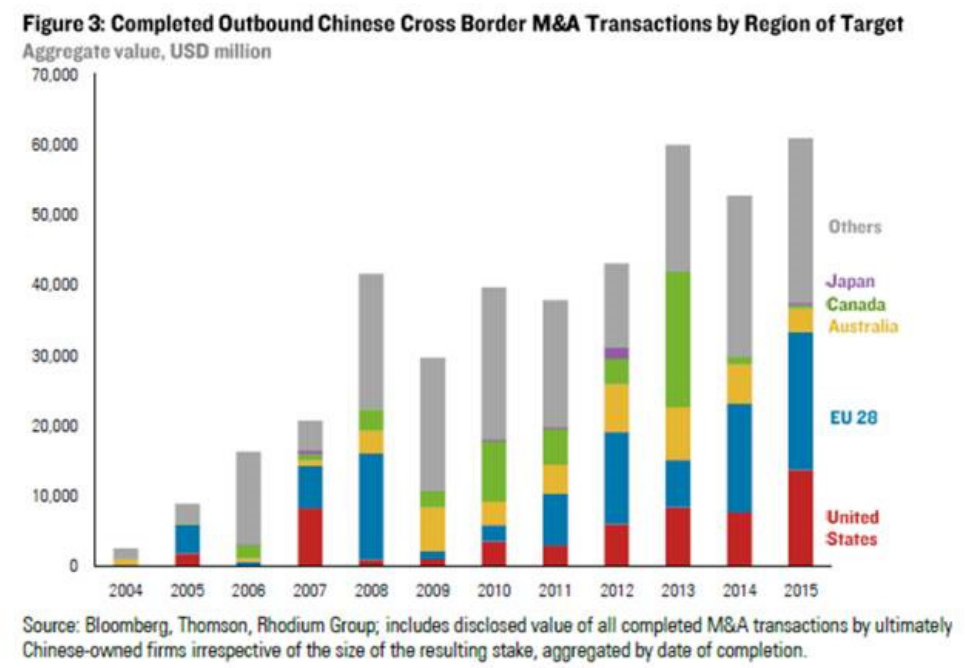

Second, because the problem is not transitional. As China specialist Frank Pieke wrote in his insightful book 'The Good Communist' published in 2009, the prospect that domestic prosperity will bring about democratic transition in China is no longer realistic. ${ }^{7}$

Tools exist. The antitrust laws of the US and the European Union ("EU") embody safeguards to address the $\mathrm{CCP} / \mathrm{SOE}$ problem. The EU has recently introduced revisions to its traditional approach. The US has so far only voiced security concerns through the Committee on Foreign Investments ("CFIUS"). ${ }^{8}$ This paper argues that the US could usefully draw inspiration from the EU and hone its antitrust powers against China.

To show this, the paper is organized as follows. First, I explain that Chinese firms organizationally operate as a CCP-led syndicate, which seems analogous to a "trust",

\footnotetext{
${ }^{5}$ For a comprehensive summary, see OECD Issues Paper, Competitive Neutrality in Competition Policy, 12 June 2015, DAF/COMP(2015)5.

${ }^{6}$ Chinese firms closed transactions worth $\$ 61$ billion in 2015 , an increase of $16 \%$ compared to 2014 . US and European companies are the two primary targets of those transactions. The US accounted for $22.8 \%$ or $\$ 13.9$ billion of completed transactions in 103 deals in 2015. The largest Chinese outbound deals announced as of the end of May 2016 were: ChemChina/Syngenta, \$43 billion; Anbang/Strategic Hotels and Resorts, \$6.5 billion; Tianjin Tianhai Investment/Ingram Micro, \$6.3 billion; Haier/GE's appliance business, \$5.4 billion; Zoomlion Heavy/Terex Corp., $\$ 4.8$ billion. See "China spends record amount buying up foreign companies", CNN Money, May 3, 2016, Sophia Yan: http://money.cnn.com/2016/05/03/investing/china-foreign-mergers-spending/

${ }^{7}$ Frank N. Pieke, The Good Communist - Elite Training and State Building in Today's China, Cambridge University Press, 2009, noting that the "weakening of the Chinese party-state has not happened. Capitalizing on rapidly rising prosperity and continued economic growth, the party-state has reinvented itself, putting the rule of the CCP on an increasingly solid footing both materially and organizationally, and, increasingly, ideologically", p. 4.

${ }^{8}$ David Shambaugh, China Goes Global - The Partial Power, Oxford University Press, 2013, noting that "In developed countries Chinese investments are questioned mainly on national security grounds”, p. 159.
} 
"combination" or "concerted practice" within the generic meaning of US and EU antitrust laws. On occasion I refer to this syndicate as a "supertrust", using the two terms interchangeably. Second, I advance that this CCP-led syndicate generates concerns similar to those that fueled social demand for antitrust regulation in the XIXth century. Third, I lay down the moral imperative for antitrust scrutiny of this CCP-led syndicate. Fourth, I discuss why the Western world cannot forbear and outsource the resolution of this problem to Chinese market governance institutions. Fifth, I show that existing antitrust rules provide a suitable remedy, and that the US should emulate the EU's recent antitrust awakening vis-a-vis China.

Prior to examining those issues, some caveats are in order. This paper is not the first to look into China's politicized corporate governance system. Many studies consider the role of the Chinese State as a corporate holding entity, and refer to it as "China Inc." Those studies focus in particular on the oversight of the State-Owned Assets Supervision and Administration Commission ("SASAC") over SOEs. This paper is distinct on two counts. To start, it does not center so much on ownership by the State, but instead seeks to discuss its political influence through party links. Moreover, given the breadth of the Chinese corporate sector, it is more realistic to describe it as a syndicated organization rather than as an integrated firm ("one big factory"). ${ }^{10}$ This is also conceptually more consistent with reported episodes of fierce competition amongst Chinese firms, ${ }^{11}$ which could not plausibly occur in a one firm scenario but which is perfectly compatible with a coordination scenario. ${ }^{12}$

Second, I should note that I have never had the opportunity to go to China. My lack of exposure to the "China Model" may admittedly affect the authority of my thesis. But I do not think that this disqualifies me from writing a paper on China's economic governance. In writing this policy paper, I have followed the conventional standards of objectivity, thoroughness and robustness that are applicable to scholarly work. And I would add that my lack of previous or ongoing dealings with China presents advantage of removing any conflict of interest, a factor which may have generated a degree of self-censorship in some Western research on China. ${ }^{13}$

\section{THE LENINIST SYNDICATE}

Lenin once prophesized that the Soviet economy should be run as a "single country-wide State syndicate". ${ }^{14}$ As a Leninist economy, China has scrupulously followed this guideline.

\footnotetext{
9 Mark Wu, "The "China, Inc." Challenge to Global Trade Governance", (2016) 57 Harvard Int'l L. J. Forthcoming, available at http://papers.ssrn.com/sol3/papers.cfm?abstract_id=2779781

${ }^{10}$ Ronald Coase said in his Nobel Prize lecture that: "Lenin had said that the economic system in Russia would be run as one big factory". http://www.nobelprize.org/nobel_prizes/economic-sciences/laureates/1991/coaselecture.html. The exact wording is: "The whole of society will have become a single office and a single factory, with equality of labour and pay”. See Lenin Collected Works, Chapter V, pp. 478-479.

${ }^{11}$ Justin Yifu Lin, Fang Cai, and Zhou Li, "Competition, Policy Burdens, and State-Owned Enterprise Reform", Vol 88 No. 2 China's Economic Reforms. The authors talk about the intensification of SOE competition in some sectors. See also Richard McGregor, The Party: The Secret World of China's Communist Rulers, HarperCollins Publishers, 2010, p. 58.

${ }^{12}$ Economists conventionally accept that industry coordination can coexist with a certain degree of competition. They call this semi-collusion.

${ }^{13}$ Mark Elvin, "China's subtle censoring of overseas scholarship, Letters”, Financial Times, January 26, 2013 : http://www.ft.com/intl/cms/s/0/a8ea50a0-64b0-11e2-934b-00144feab49a.html\#axzz49Yc3bUYZ

${ }^{14}$ Lenin collected works, Chapter V, p. 478.
} 
A fact little known by Westerners is that a CCP cell is embedded in each Chinese SOE, ${ }^{15}$ a requirement of Chinese law. ${ }^{16}$

Party cells can be best understood as tentacles of the CCP. ${ }^{17}$ Their best documented role concerns human resources and in particular the appointment and career management of senior executives. In addition, Party cells have a less conspicuous say on all "important and material matters" of corporate policy. ${ }^{18}$ In an insightful academic article, Jiangyu Wang, an Associate Professor with the National University of Singapore, sheds light on the opaque functions discharged by Party cells. The abstract concept of "important matters" covers development strategy, production and business operation policies, annual budget, etc. ${ }^{19}$ Wang also explains that CCP internal directives require SOEs to ensure effective participation of Party cells in decision-making, including decisions by the board of directors, supervisory board and management team. ${ }^{20}$ This role includes educational tasks. In May 2015, it was officially reported on ChemChina's website that its President Ren Jianxin had officially "followed the instructions of $[\ldots]$ the ChemChina Party committee to carry out a special Party principle lecture on clean acts and practical work". A total of "356 people attended the lecture, including ChemChina's leadership, heads of its departments and subsidiaries, as well as science worker representatives". ${ }^{21}$ Last, Party cells must report to the CCP "anything

${ }^{15}$ Li-Wen Lin, "State Ownership and Corporate Governance in China: An Executive Career Approach", (2013) 3 Columbia Business Law Review Rev. 743-800. Richard McGregor, supra at p. 15, perhaps illustrative of how well hidden this fact is, McGregor at page 17, recollects a dinner in China with media mogul Rupert Murdoch, where the latter declared "he had yet to meet any communists during his trip to China". Earlier, the World Bank had declared that "the Chinese corporate form has become the vehicle for separating governmental and business functions" (1997). China - Management of Enterprise Assets. The State as Shareholder. Washington, D.C.: World Bank.

${ }^{16}$ See Article 19 Company Law of the People's Republic of China (Revised in 2013), Promulgation Date 201312-28; Promulgation Number; Promulgation Department: Standing Committee of the National People's Congress: "In a company, an organization of the Communist Party of China shall be established to carry out the activities of the party in accordance with the charter of the Communist Party of China. The company shall provide the necessary conditions for the activities of the party organization". Alan Riley, "West should be on its guard against Chinese investment wave", Financial Times, Letters, April 1, 2016: "It is clear from modern academic scholarship that China's Communist party has influential party committees in every state-owned enterprise and large private company in China. These committees have a direct impact on the policy direction, recruitment and funding of SOEs and significant private companies".

17 XinXiang Chen, "Modes of State Intervention and Business Group Performance in China's Transitional Economy", (201) The Journal of Socio-Economics 39 619-630 at p. 621: "the CCP still retains coordination rights alongside the government bureaucracy [...]. The Chinese state can draw on party committees, which are in essence networks of political actors internal to the firm, to support its policy initiatives and to provide timely and detailed information about personnel and other matters, thus controlling social and economic activities".

${ }^{18}$ Jiangyu Wang, "The Political Logic of Corporate Governance in China's State-owned Enterprises", (2014) Cornell International Law Journal Vol. 47, at p. 631: "The responsibilities and powers of the Party organization in an SOE are more explicitly stated in the 1997 CCP Notice on Party Building in SOEs, which requires the Party organization to supervise the enterprise in order to ensure that the CCP line is faithfully implemented, and authorizes it to "participate in the decision-making on material and important matters of the SOE and provide support to the factory leader/general manager, shareholders' general meeting, board of directors and supervisory board to perform their duties according to law. Accordingly, the board of directors or general manager is required to "consult and respect the opinion of the Party organization" before making any important decisions, and brief the Party organization on the implementation of said decision".

${ }^{19}$ Id., quoting at p. 656 a 2004 Decision that defines the "material and important matters" as: "the SOE's development strategy, medium and long-term planning, production and business operation policies, annual financial budget and financial accounts, corporate asset restructuring, the drafting of the enterprise's major reform plans and key rules and institutions of management, the enterprise's important personnel arrangements, as well as issues of vital personal interests to the workers".

${ }^{20}$ Id., p. 657.

${ }^{21}$ See http://www.chemchinapetro.com.cn/youqien/xwymt/gsxw/webinfo/2015/05/1435105223987851.htm. The press release further noted: "Participants said that Ren's lecture contained rich information and was practical. 
materially inconsistent with the Party's line or policies, state laws, or anything that is divorced from reality". All in all, Wang concludes that the combined effect of those prerogatives is to "make the SOE an economic entity almost completely controlled by the CCP". ${ }^{22}$

Hard empirical evidence of the CCP's grip on SOEs does not exist. Non-disclosure of the Party's influence in SOE governance and of managers' political connections is a policy choice. ${ }^{23}$ Moreover, the secrecy surrounding the CCP's role in corporate governance occurs with the complicity of many occidental observers: investment bankers, law firms and consultants have incentives to paint an attractive picture of SOEs to foreign investors. ${ }^{24}$ Last, self-censorship by Western academics exposed to potential visa denial or the loss of Chinese students' fees in university education programs appears to be widespread. ${ }^{25}$

Journalists seem to have fewer constraints. In his 2010 book, The Party: The Secret World of China's Communist Rulers, former Financial Times China Bureau Chief Richard McGregor documents anecdotes of the Party's role in business. He talks of the 4 digit "red machine" that sits on the desk of CEOs of State companies and that serves as the CCP "hotline". He recounts the testimony of a Chinese lawyer: "in corporate law, the boards [of Chinese state companies] can choose to disregard the Party's advice. As a fact of life, they cannot". ${ }^{26}$ McGregor also relates telling stories. He writes that in 2005, the true reason for the failure of China's CNOOC bid for US Unocal was due to the way that CNOOC's chief executive, Fu Chengyu, mismanaged the competing demands of the CCP and the independent foreign directors of CNOOC's board in configuring the bid. Similarly, McGregor explains in minute detail how, in 2007-2008, the Politburo of the CCP orchestrated Chinalco's counter bid for Rio Tinto, which included directly influencing the company's chairman Xiao Yaqing, who is now Chairman of SASAC (and who had been parachuted into a CCP position following his departure from Chinalco). ${ }^{27}$

Importantly, CCP control extends beyond SOEs. Privately-owned enterprises ("POEs") are also subject to CCP supervision, through classic Soviet-style arrangements. Placement of Party cadres is one of them. CCP policy dictates that a corporate manager of a given rank

The lecture pointed the way for their future education and work. They said that they would follow instructions from Ren".

${ }^{22}$ Id., p. 658.

${ }^{23}$ Richard McGregor, supra at p. 48. In this context, a 2012 report of the US Congress Permanent Select Committee on Intelligence lambasted the flawed disclosure practice of Chinese firms, and recommended that "Chinese companies should quickly become more open and transparent, including listing on western stock exchanges with advanced transparency requirements, offering more consistent review by independent third-party evaluators of their financial information and cyber-security processes, complying with U.S. legal standards of information and evidentiary production, and obeying all intellectual-property laws and standards". See 112th United States Congress, Investigative Report on the U.S. National Security Issues Posed by Chinese Telecommunications Companies Huawei and ZTE, Report by Chairman Mike Rogers and Ranking Member C.A. Dutch Ruppersberger, October 8, 2012.

${ }^{24}$ Li-Wen Lin, "State Ownership and Corporate Governance in China: An Executive Career Approach", (2013) 3 Columbia Business Law Review Rev. 743-800. See also, ChemChina’s Global Shopping Spree Is Debt-Fueled, The Wall Street Journal, March 10, 2016, Kane Wu, noting that private banks including non-Chinese provide credit as well: "Chinese and foreign banks have proven eager lenders. J.P. Morgan Chase \& Co. provided a \$7.4 billion bridge loan for the Pirelli purchase".

${ }^{25}$ Censors without Borders, New York Times, May 14, 2010, Emily Parker.

${ }^{26}$ Richard McGregor, supra at p. 68 adds: "with the need to be profitable and compete globally, top executives of state enterprises these days have a relative freedom to run their businesses inconceivable a decade ago ... but through the reform of the sector, the party has retained its influence by maintaining power over all senior appointments. Through personnel, they can in turn direct corporate policy". ${ }^{27} \mathrm{Id}$. 
typically simultaneously holds a position of equivalent rank in the Party system. Milhaupt and Zheng find that in "ninety-five out of the top one hundred private firms and eight out of the top ten Internet firms the founder or de facto controller is currently or formerly a member of central or local Party-state organizations such as People's Congresses and People's Political Consultative Conferences". ${ }^{28}$ Extralegal means, like the setting up of Governmentengineered trade associations, industry alliances, and chambers of commerce, are another such Soviet-style arrangement. ${ }^{29}$

If all of the above is true, then the Chinese economic system can be organizationally conceptualized as a "combination in the form of trust or otherwise" within the meaning of Section 1 of the US Sherman Act or as a "concerted practice" or "association of undertakings" within the meaning of Article 101 of the Treaty on the functioning of the EU ("TFEU"). Though their research relates to Chinese corporate governance, Lin and Milhaupt actually come very close to attaching this "trust" label to China's economic organization when they write that "Chinese state capitalism of the past thirty years represents a form of industrial organization that produces substantial benefits to members of the encompassing coalitionthe managerial elite with control over economic policy formation and implementation within the party-state system". ${ }^{30}$

Indeed, given its vast scale and ambition, one can characterize the Chinese economic system as a supertrust. It creates backchannels between SOEs and POEs within a given industry. But at the CCP central level, it enmeshes all SOEs and POEs, regardless of whether they compete in the same business area. ${ }^{31}$ This goes far, far beyond anything the US industrialists of yore ever conceived. ${ }^{32}$

\section{GRASSROOTS ANTITRUST}

Ernest Geelhorn and Bill Kovacic have conceptualized the three concerns that fueled social demand for antitrust regulation in the United States in the late XIXth century: ${ }^{33}$ the endangering of democratic institutions, predatory tactics for subduing rivals, and outrageous methods to achieve unreasonable ends beyond destroying competitors. ${ }^{34}$ In many respects, the CCP-led syndicate's operation raises similar concerns.

The danger posed to democratic institutions is perhaps the easiest to understand. ${ }^{35}$ The syndicated organization of China provides it with hard power over foreign affairs. As much as John Rockefeller could steer lawmaking to his benefit with threats of exorbitantly priced

\footnotetext{
${ }^{28}$ Curtis J. Milhaupt and Wentong Zheng, “Beyond Ownership: State Capitalism and the Chinese Firm”, (2015) 103 Geo. L.J. 665.

${ }^{29} \mathrm{Id}$.

${ }^{30}$ Li-Wen Lin and Curtis J. Milhaupt, "We Are The (National) Champions: Understanding the Mechanisms of State Capitalism in China”, (2013) Stanford Law Review, Vol. 65:697, p. 752.

${ }^{31}$ Fashion Originators' Guild of America, Inc. v. Federal Trade Commission 312 U.S. 457 (1941) is an example of a supertrust. In this case, the US Supreme Court affirmed antitrust liability against the boycott conduct of competing and non-competing garment designers, manufacturers and sellers as well as manufacturers, converters or dyers of textiles through a guild.

${ }^{32}$ And the reported trend is to increase CCP control over SOEs. See China Rows Back on State-Reform Sector, The Financial Times, June 4, 2016, Lucy Hornby.

${ }^{33}$ I borrow the term "grassroots" from Tim McNeese, The Robber Barons and The Sherman Antitrust Act, Chelsea House, 2008.

${ }^{34}$ Ernest Geelhorn and Bill Kovacic, Antitrust Law and Economics in a Nutshell, 1994, West Group, pp. 17-18.

${ }^{35}$ David K. Millon, "The Sherman Act and the Balance of Power", 61 S. Cal. L. Rev. 1219 (1988); Robert Pitofsky, “The Political Content of Antitrust”, (1979), University of Pennsylvania Law Review, Vol. 127: 1051.
} 
oil, the CCP can use its leverage over the "workshop of the world" to blackmail governmental, non-governmental and international organizations. ${ }^{36}$ Our global leaders' deafening silence on Chinese political and human rights issues lends empirical support to this argument. But this is not all. The syndicate exerts "soft power" in third countries, through the CCP cells embedded in overseas Chinese companies. Where there are Chinese firms, one can safely assume that there are Party organizations and Party activities. ${ }^{37}$ And it is wellknown that the $\mathrm{CCP}$ "has always accepted that [...] people must be indoctrinated", including outside of China. ${ }^{38}$

Second, the rapacious anticompetitive tactics of old-style US trusts seem to have timetravelled to contemporary China. Much as in the 1911 Standard Oil Co. of NJ v United States case where Rockefeller leveraged preferential railroads rebates to subdue rivals, ${ }^{39}$ Chinese firms compete on an unequal footing with international competitors thanks to concessionary credit provided by comrade financial institutions. ${ }^{40}$ Likewise, the tobacco trust's brute force acquisition and shutdown of 30 rival plants in the 1911 United States v American Tobacco case resonates when one pauses to reflect on the implications of the ongoing wave of foreign acquisitions by Chinese firms. ${ }^{41}$ The parallels with the behavior of the XIXth century robber barons are even stronger if one considers the sectors besieged by overcapacity, such as steel ${ }^{42}$ or fragmented industries such as travel services. ${ }^{43}$

Last, if odious conduct was a distinctive trait of the classic US trusts, this too could be second nature for the Chinese supertrust. Compare Gellhorn and Kovacic's description of the ruthless XIXth century US economic landscape ("investors were defrauded by watered stocks; workers were discarded as worn out tools ...; liberty was endangered by bribery of public officials ..." $)^{44}$ with contemporary reports on China ("China's rampant theft of intellectual

\footnotetext{
${ }^{36}$ David Shambaugh, China Goes Global, at p. 158.

${ }^{37}$ Id. p. 188: "Chinese companies are politicized. That is, many have Communist Party cells, secretaries, and members embedded within the firm. In 2010, exactly half of the CEOs of China's 109 "national champion" firms under government control were appointed by the Organization Department of the CCP. This is true of multinational corporations as well. As the newspaper of the Central Party School pithily observed in an article about establishing party branches in companies operating abroad, "Where there are people, there are Party organizations and Party activities".

${ }^{38}$ China's Soft Power Push, Foreign Affairs, July/August 2015 Issue, David Shambaugh.

${ }^{39}$ See Standard Oil Co. of New Jersey v. United States 221 U.S. 1 (1911).

${ }^{40}$ Curtis J. Milhaupt and Wentong Zheng, supra at p. 690: "abundance of empirical evidence indicates that the political connections of firms in China are a strong indicator of their access to bank loans". See also, A "Gut Check" On U.S.-China Policy, Council on Foreign Relations' Asia Unbound blog/Forbes, April 5, 2016 Elizabeth Economy: "On deeper reflection, however, the answer may well be that Chinese state-owned companies-or even private companies with opaque sources of financing that likely include the Chinese government-may demand an additional layer of scrutiny". See National service is not whipping China's banks into shape, Financial Times, March 8, 2016, Henny Sender, reporting that the acquisition of Syngenta by ChemChina is supported by a loan from a small mainland bank, Citic, all this being engineered through political connections at the highest level.

${ }^{41}$ See "China's buying up foreign companies, so the U.S. might need to rethink its trade strategy", The Washington Post, April 3, 2016, Editorial Board, which suggests that acquisitions are the first step of a strategy to develop domestic capability, and then block imports from the Western world.

${ }^{42}$ See China's State-owned zombie economy, Financial Times, February 29, 2016, Gabriel Wildau.

${ }^{43}$ See Chinese travel giants HKCTS Group, CITS Group mull merger to create largest travel service company in Asia, subject to approvals, MLex, February 24, 2016, reporting that China National Travel Service (HK) Group Corporation, or HKCTS Group, and China International Travel Service Group Corporation, or CITS Group, are contemplating a "strategic reorganization" to create the largest travel service company in Asia.

${ }^{44}$ Ernest Geelhorn and Bill Kovacic, supra at p. 18.
} 
property"; "China's counterfeit culture runs deep",46 "China has deployed [...] forced technology transfer [and] manipulative standard setting"). ${ }^{47}$ Can all of this be blamed on the Chinese supertrust? That would be excessive. That said, a number of China specialists observe that members of the syndicate are the beneficiaries of such extractive maneuvers. Chinese state-owned steel producers Baosteel Group and the Hebei Group were suspected of being the primary beneficiaries of recent cyber theft attacks against US Steel. ${ }^{48}$ And the recent shutdown in China of Apple's iBook Stores and iTunes Movies has in part been driven by favoritism for indigenous rivals such as Huawei, Alibaba and Tencent. ${ }^{49}$

\section{MORAL IMPERATIVE}

The moral case for an antitrust reaction is easier to lay out. In recent years, public confidence in open markets that bring in foreign competition has been fraying at the seams. The growing opposition to ongoing trade partnership negotiations in the West is a visible symptom of this. The increasing political clout of anti-establishment and populist parties with anti-free trade agendas is another indicator of the public's diminishing confidence in open markets.

Chinese competition in Western markets has likely meant distortions in the level playing field, engineered by systemic subsidization, currency manipulation and extractive labor market relations. ${ }^{50}$ This has eroded the political capital of the West's "open door" trade policies. A widespread realization that doing business with China means opening the door to a syndicate of firms, coordinated backstage by the $\mathrm{CCP}$, could be the final nail in the coffin for our current free trade system.

The collateral damage of doing business with the Chinese supertrust could indeed fuel further demands for a blanket abandonment of free and competitive trade across the board, including with nations which, unlike China, do have effective market governance institutions. This would in practice deny Western citizens the benefits of legitimate competitive imports.

The risk of a backlash reinforces the pressing need for antitrust attention to the CCP-led supertrust, and may help forestall the emergence of an even greater anti-free trade platform than we presently observe. After all, the core raison d'être of antitrust regimes is reflective of Western societies' moral commitment to promote competition in all of its forms. The objection that this is a trade issue is in our view irrelevant. As George Stigler wrote in a paper titled "The Economists and the problem of monopoly": "Free trade is a sort of international antimonopoly program in itself". ${ }^{1}$

\section{IV. “POTEMKIN" INSTITUTIONS BY DESIGN}

\footnotetext{
${ }^{45}$ David Shambaugh, China's Future at p. 44. Shambaugh also writes, in his book China Goes Global: The Partial Power, that "a variety of discriminatory trade and investment practices plague European (and other) businesses in China, particularly the continuing widespread theft and pirating of intellectual property", p. 90.

${ }^{46}$ Paul Midler, Poorly Made in China, an Insider's Account of the Tactics behind China's Production Game, John Wiley \& Sons, Inc., 2009, p. 116

${ }^{47}$ Stephen J. Ezell and Robert D. Atkins, "False Promises: The Yawning Gap Between China's WTO Commitments and Practices", Information Technology \& Innovation Foundation, September 2015.

${ }^{48}$ U.S. Steel accuses China of Hacking, Wall Street Journal, April 28, 2016, J. Miller.

${ }^{49}$ Apple no longer immune to China's scrutiny of U.S. tech firms, New York Times, April 21, 2016, Paul Mozur \& Jane Perlez.

${ }^{50}$ David Shambaugh, China Goes Global - The Partial Power, supra at p.127.

${ }^{51}$ George J. Stigler, "The Economists and the Problem of Monopoly" (1983) University of Chicago Law Occasional Paper No. 19.
} 
To date, discontents with the Chinese supertrust have been told to channel their grievances through domestic market governance institutions. Since Deng Xiao Ping's ideological U-turn in 1978, China has progressively rolled out the basic legal infrastructure of a market economy: private property, freedom to compete, freedom to contract, a court system and the rule of law. China's accession to the WTO in 2001 prompted further adjustments geared to international best practice. ${ }^{52}$ As part of this "marketization" process, and following a 13 year genesis, China adopted a Western-spirited Anti-Monopoly Law in 2007, ${ }^{53}$ and vested enforcement powers in three agencies, namely the Ministry of Commerce of the Republic of China ("MOFCOM"), the State Administration for Industry and Commerce ("SAIC") and the National Development and Reform Commission ("NDRC"). ${ }^{54}$

\section{But does this market governance infrastructure provide an effective remedy?}

Since 2007, much ink has been spilt by academics and practitioners on the neutrality (or lack thereof) of Chinese antitrust enforcers in their application of Chinese competition law to foreign firms. ${ }^{55}$ Yet this debate invariably misses the point. The Chinese enforcement system is broken by design. Qianlan $\mathrm{Wu}$ (who stops short of reaching such a controversial conclusion) explains: "The Chinese market governance is subject to a monist regulatory framework where the party-state has remained to be [sic] a dominant, resilient and strategic actor". ${ }^{56} \mathrm{He}$ adds: "the CCP functions as a shadowing institution behind the state apparatus and directs decision making by these organs". ${ }^{57}$

A quick Internet search seems to corroborate this analysis. MOFCOM Chairman Gao Hucheng, SAIC chief Zhang Mao, and NDRC Chairman Xu Shaoshi are all full members of the Central Committee of the CCP. ${ }^{58}$ And Xiao Yaqing, Chairman of SASAC, is a member of the Central Commission for Discipline Inspection, which reports directly to the Politburo, the decision-making body of the CCP. ${ }^{59}$

\footnotetext{
52 For a thorough review, see Qianlan Wu, Competition Laws, Globalization and Legal Pluralism, Hart Publishing, 2013 at Chapter 3.

${ }^{53}$ Anti-Monopoly Law of the Republic of China, [2008] Presidential Order No. 68, August 30, 2007 (“AML”). The law is very close in wording to the EU competition rules, but also has specific language which reflects an ambition to promote the socialist market economy, and China's specificities. See Qianlan Wu, supra at pp. 133.

${ }^{54}$ MOFCOM carries out merger control, the NDRC enforces the AML against price related restraints of competition, and SAIC enforces the AML against non-price related anticompetitive practices. Incremental progress towards a true competition culture is being pursued through participation in international networks of antitrust enforcers.

${ }^{55}$ D. Daniel Sokol and Wentong Zheng, "FRAND (and Industrial Policy) in China", Cambridge Handbook of Technical Standardization Law, Vol. 1: Antitrust and Patents, (2017) Forthcoming. Available at http://papers.ssrn.com/sol3/papers.cfm?abstract_id=2776235. Sokol and Wentong believe that industrial policy concerns may have influenced the Chinese agencies' analysis in several high profile merger and monopolization cases involving large US technology firms. Others consider that the AML has not been enforced in a manner that discriminates against foreign companies. Wendy $\mathrm{Ng}$, "Policy Objectives of Public Enforcement and the AntiMonopoly Law: An Assessment of the First Five Years" in Adrian Emch and David Stallibrass (eds), China's Anti-Monopoly Law, The First Five Years, Wolters Kluwer Law \& Business, 2013, p. 56.

${ }^{56}$ Qianlan $\mathrm{Wu}$, supra at p. 72.

${ }^{57} \mathrm{Id}$.

${ }^{58} \mathrm{http}: / /$ www.china.org.cn/china/18th_cpc_congress/2012-11/14/content_27114945.htm

${ }^{59} \mathrm{http}$ ://www.china.org.cn/china/18th_cpc_congress/2012-11/15/content_27123718.htm
} 


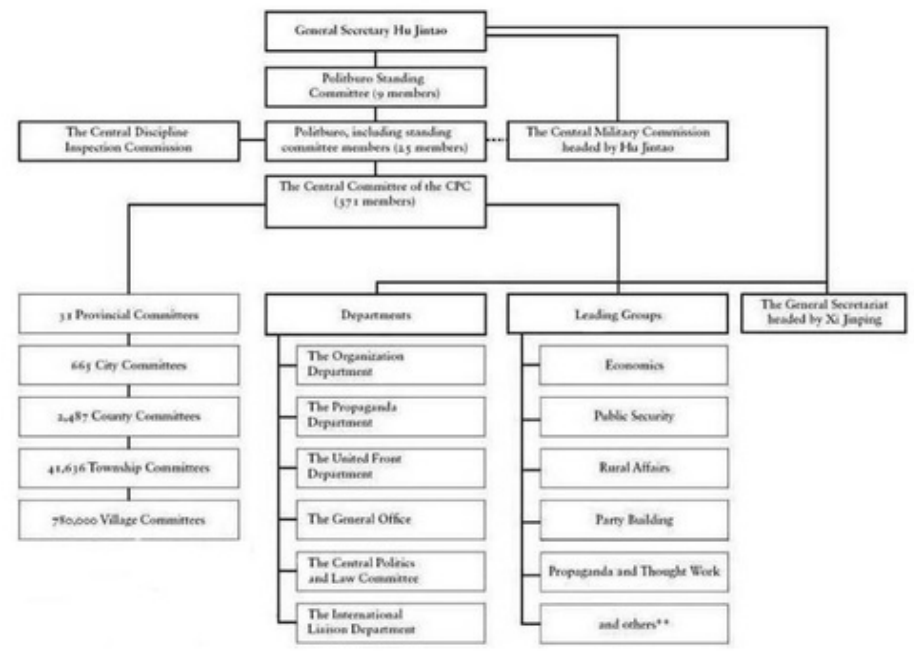

Source: R. McGregor's, The Party: The Secret World of China's Communist Rulers, 2010

Moreover, the CCP's influence diffuses top-down through decisional silos. McGregor explains: "the officials working in public institutions are trained, and re-trained, at regular intervals, through the Party's extensive nationwide network of 2,800 schools". ${ }^{60}$ And in the judiciary, which is supposed to review antitrust enforcers' decisions, the Party is also in the driver's seat: "The Lawyer's association, the Justice Bureau, and indeed any legal body ... come under the control of the Politics and Law Committee" of the Politburo. ${ }^{61}$ In 2015, the US Department of State noted in its annual statement on the investment climate in China that: "Generally, unlike the United States, the legal system is designed to serve state and Communist Party interests, and as such, does not consistently protect individual rights or effectively resolve disputes". ${ }^{6}$

In scholarly circles, China's antitrust institutional design has occasionally been criticized, in particular, its lack of agency and judicial independence from the executive branch. ${ }^{63}$ But our argument here is that the issue cuts far deeper. As Alan Riley writes, regulatory agencies "are all Potemkin institutions [...] the central economic role remains with the Chinese Communist Party" ${ }^{64}$ With all this, as long as Leninism, and its corollary centralism, ${ }^{65}$ remain China's doctrine, no Montesquian reform of any kind - like, for instance, structural separation of antitrust agencies from executive power - seems likely to ever change anything.

A plausibly stronger objection to our claim that economic governance is broken by design is that the CCP is not a monolithic party. Two schools of thought compete for leadership within it: the conservatives, committed to keeping the Party State in charge, and the reformists, supportive of market-oriented reforms and Western style governance. ${ }^{66}$ In today's China,

\footnotetext{
${ }^{60}$ Richard McGregor, supra at p. 15.

${ }^{61} \mathrm{Id}$.

${ }^{62}$ US Department of State, China Investment Climate Statement 2015, p. 5: See http://www.state.gov/documents/organization/241728.pdf

${ }^{63}$ On the lack of independent judicial review, see Angela Zhang, "Bureaucratic Politics in China's Antitrust Enforcement”, Concurrences N³-2015 I Conference I New Frontiers of Antitrust 2015 I Paris, 15 June 2015. On the division into three distinct agencies, see Hao Quian, "The Multiple Hands: Institutional Dynamics of China's Competition Regime", China's Anti-Monopoly Law, The First Five Years, (2013) supra at p. 15.

${ }^{64}$ Alan Riley, Chinese Investment: The West Needs to take off its Ideological \& Regulatory Blinkers. Available at https://www.linkedin.com/pulse/chinese-investment-west-needs-take-off-its-regulatory-alan-riley

${ }^{65}$ Folke Dovring, Leninism - Political Economy as Pseudoscience, Praeger Publishers, 1993, pp. 105-106.

${ }^{66}$ David Shambaugh, China's Future, supra at p. 99.
} 
however, the conservatives are in charge, and there is no prospect of fundamental change in the medium term. Since coming to power, President Xi Jinping has relentlessly reasserted CCP controls over China's institutional landscape. ${ }^{67}$ In March 2016, a Time Magazine piece labeled President Xi as "China's Chairman" in its headline, noting that he had taken "personal control" "of everything from the economy, national security and foreign affairs to the Internet, the environment and maritime disputes". ${ }^{6}$ Kennedy and Johnson note that "The CCP has always been in charge, but under Xi Jinping, the CCP has asserted itself and become more involved in the day-to-day work of governance. Xi Jinping oversees every major policy decision." ${ }^{69}$ The 13th Five Year Plan, adopted in March 2016, is the first ever to have a chapter "dedicated to strengthening the leadership role of the CCP in society."

\section{WESTERN ANTITRUST AWAKENING}

With all this, antitrust agencies from North America and Europe and beyond should not defer to the review undertaken by Chinese domestic antitrust institutions. Given the scale of the CCP nomenklatura, the antitrust system can be suspected of lacking "competitive neutrality". ${ }^{71}$ At the operational level, we sketch out below two modest and concrete steps that Western antitrust agencies should take in merger and antitrust cases involving Chinese firms.

\section{A. TREAT ALL CHINESE ACQUIRERS AS PART OF A SINGLE BROAD SYNDICATE IN MERGER REVIEW}

The operation of the Chinese syndicate is a competition problem ${ }^{72}$ that justifies a comprehensive review beyond narrow CFIUS-style security concerns. ${ }^{73}$ Let us envisage the following hypothetical M\&A scenario: Chinese SOE A makes a \$50 billion hostile all-cash offer to acquire a Western competitor, $X{ }^{74}$ The take-over is financed with debt obtained under highly favorable conditions from Chinese SOE bank B and conducted via two small

\footnotetext{
${ }^{67}$ Id, p. 119.

${ }^{68}$ See China's Chairman Builds a Cult of Personality, Time Magazine, March 31, 2016, Hannah Beech.

${ }^{69}$ Scott Kennedy \& Christopher K. Johnson, Perfecting China, Inc. The 13th Five-Year Plan, Center for Strategic \& International Studies, May 2016, p. 11: https://csis-prod.s3.amazonaws.com/s3fspublic/publication/160521_Kennedy_PerfectingChinaInc_Web.pdf

${ }^{70}$ Id at p. 35. These five-year plans are significant, similar to a Western political party manifesto.

${ }^{71}$ See OECD, Roundtable on Competition Neutrality, Note by Nicolas Petit, Implications of Competitive Neutrality for Competition Agencies: a Process Perspective, DAF/COMP/WD(2015)50, June 11, 2015.

${ }^{72}$ See Lin \& Milhaupt supra: "The networks we describe most likely produce countervailing effects: They enhance efficiency by fostering information sharing, reducing opportunism through repeat play, providing highpowered incentives, and reducing frictions in policy implementation. But they also reduce competition and transparency, multiply agency relationships, and soften budget constraints".

${ }^{73}$ China's Voracious Appetite, Bloomberg Gadfly, March 21, 2016, Tara Lachapelle and Rani Molla: "China's Tsinghua Unisplendour did cancel a plan to make a large investment in Western Digital last month because it faced an investigation by the Committee on Foreign Investment in the U.S., or CFIUS, as the agency is known"; Foreign Ownership in the U.S. Agricultural Sector, AgWeb, April 6, 2016 Stephanie Mercier: "Between 1988 and 2014, there were 2,624 notifications of foreign purchases of U.S. entities through the federal CFIUS process. About 12 percent of those transactions were investigated, and in only 15 cases did the President intervene to block the sale, although 131 other sales were withdrawn due to public concerns".

${ }^{74}$ I borrow the hypothesis from China's Looming Currency Crisis, The Wall Street Journal, March 16, 2016, Anne Stevenson-Yang and Kevin Dougherty: "Chinese companies are making extravagant bids for overseas assets such as General Electric's appliance division, the equipment maker Terex Corp., the near-dead Norwegian Web browser Opera, the Swiss pesticides group Syngenta, technology distributor Ingram Micro and even the Chicago Stock Exchange".
} 
subsidiaries $\mathrm{C}$ and $\mathrm{D}$ respectively registered in the Netherlands and Delaware. Ahead of any possible notification of the transaction to regulatory authorities in the US, the EU and China, MOFCOM announces that it "supports" the acquisition and calls on other countries to treat the deal "objectively and rationally". ${ }^{75}$ A protracted discussion takes place with antitrust agencies as to whether the parties' turnover exceeds the thresholds that mandate prior notification. ${ }^{76}$ Moreover, the nature of the links between SOE A and two other POEs in the same sector $(\mathrm{E}$ and $\mathrm{F})$ is under discussion, all three being members of the same Chinese trade association and having a Party cell.
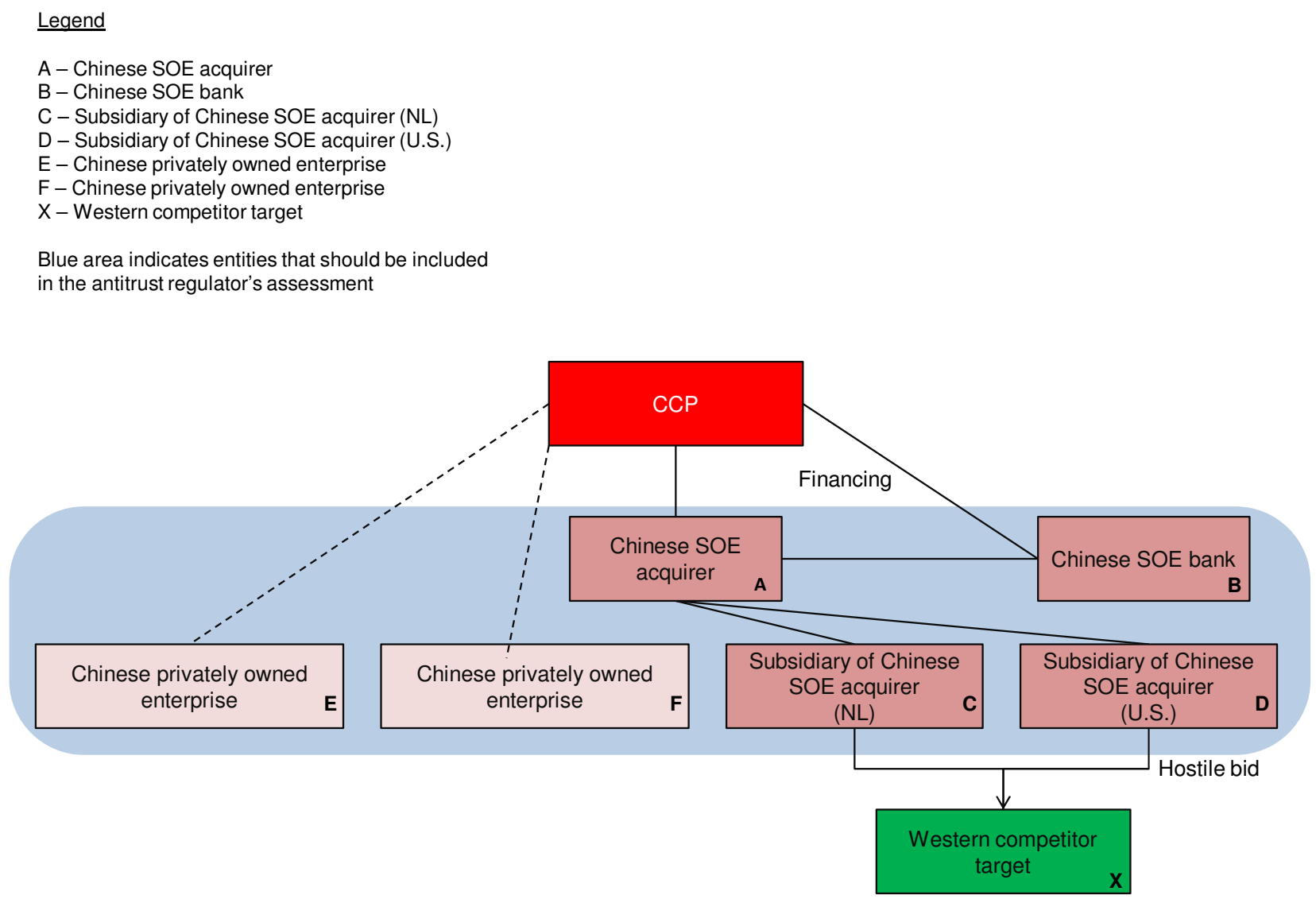

With this background, let us detail our proposal. In merger review, all Chinese SOE and POE acquirers with a Party cell should be viewed by antitrust regulators as part of the single broader syndicate that comprises all other SOEs and POEs. ${ }^{77}$ We do not restrict our proposal to a specific industry, because this would leave out other upstream or downstream firms

\footnotetext{
${ }^{75}$ See transcript of MOFCOM press conference of February 17, 2016, during which MOFCOM's Shen Danyang commented on the ChemChina/Syngenta transaction, available at http://english.mofcom.gov.cn/article/newsrelease/press/201602/20160201259396.shtml

${ }^{76}$ While merger control rules in most jurisdictions are mandatorily triggered when specified turnover thresholds are exceeded, some jurisdictions use market share or other tests. A few countries, such as the UK, Australia and New Zealand have voluntary regimes but notifications are then usually advisable and/or expected if certain substantive bright line tests are met.

${ }^{77}$ To be consistent, the approach should cover all private firms with a Party cell. As explained by Mark Wu: "Each organization with more than three Communist Party members is required to form a party committee within the organization. This extends to not only SOEs, but also private companies and foreign firms". See Mark Wu, supra, p.20.
} 
which can influence the conditions of competition within the industry (such as input suppliers, for example electricity, oil or raw material suppliers). The broad syndicate will also include SOE banks, where financial firepower is plainly at the service of SOE acquirers. ${ }^{78}$

In this scenario, Chinese SOE and POE acquirers cannot skirt mandatory merger control thresholds in the US and the EU by using subsidiaries that generated limited turnover as a front for the transaction (in our hypothetical scenario, C and D) and designating them as the sole acquirers of the purchased assets. Moreover, the aggregation of all SOEs and POEs should reflect the true magnitude of anticompetitive overlaps during the analysis of the transaction. Concretely, antitrust agencies will not only consider the aggregated market shares of $\mathrm{A}$ and $\mathrm{X}$, but also include all competing SOEs and POEs with a Party cell as members of the Chinese supertrust (here, $\mathrm{E}$ and F).

To date, US antitrust regulators have not grappled with the issue of whether a Chinese acquirer should be viewed as part of the broader syndicate. In contrast, EU and Australian practices in relation to SOEs (but not POEs) are more established. ${ }^{79}$ In the EU, the EU Commission - the agency in charge of merger review - accepts the need to look beyond nominal shareholding and governance structures, and focuses on whether SOEs have an "independent power of decision". In the Hinkley Point decision in March 2016, the EU Commission considered all Chinese SOEs in the energy sector to form a single economic unit. ${ }^{80}$ If the EU Commission had taken the narrow view that each SOE is a distinct entity for antitrust purposes, it could not have reviewed the proposed joint venture since that SOE's EU turnover was below the jurisdictional thresholds.

To reach this finding, the EU Commission essentially referred to Chinese statutory provisions that grant SASAC supervisory control over SOEs. This approach is pragmatic. With this, the EU Commission is not dragged into the consideration of unverifiable defenses that SASAC control is not actually exercised.

In our view, the US and EU agencies could equally rely on the organic existence of a CCP Party cell within each Chinese acquirer in order to establish the existence of a single economic unit. This may then entitle the EU Commission to review transactions involving Chinese acquirers which do not have SOE status (in our hypothesis, F acquires a European competitor) or to demonstrate the true magnitude of wider anticompetitive overlaps with rival POEs $(\mathrm{A}+\mathrm{E}+\mathrm{F})$.

\footnotetext{
${ }^{78}$ See for example, The Wall Street Journal, Feb. 28 2016, How China Inc. Plans to Pay for Biggest Overseas Deal, Kane Wu: http://www.wsj.com/articles/chemchina-finds-banks-eager-to-loan-billions-for-syngenta-deal1456650286

${ }^{79}$ In 2009, the Australian Competition and Consumer Commission (“ACCC”) reviewed Chinalco's proposed acquisition of Rio Tinto. It listed a number of conditions and assumptions that would be necessary for a competition concern to arise, the third of which was that Chinalco, the Chinese government, and Chinese purchasers of iron ore (i.e. Chinese steel mills) would have to be considered for the purposes of the competition assessment as a single entity.

${ }^{80}$ See Commission Decision, EDF/CGN/NNB Group of Companies, Case M.7850, March 10, 2016. For comprehensive treatment and early analysis, see Alan Riley, "Nuking Misconceptions: Hinkley Point, Chinese SOEs and EU Merger Law (May 10, 2016) available at http://papers.ssrn.com/sol3/papers.cfm?abstract_id=2778229
} 


\section{ASSUME UNDERLYING COORDINATION SCHEME IN ANTITRUST INVESTIGATIONS}

An additional concept that could be further investigated in future research is that Chinese firms' anticompetitive conduct in North American and European markets should be investigated on the default assumption of a subjacent coordination scheme. In my view, this proposition ought to be uncontroversial and should be considered nothing more than an adaptation of competition rules to accommodate the Chinese corporate paradigm. Imagine that, post-merger, A engages in rapacious below-cost pricing in Europe or that it performs acts of industrial espionage. Given the organizational structure of the syndicate - notably that all senior executives and management at Chinese SOEs are appointed by the CCP's Organization Department- it can be presumed that the benefits of A's predatory conduct will be shared with $\mathrm{E}$ and $\mathrm{F}$, and that stolen technology will be also transferred to them and other members of the Chinese supertrust.

And it has an important added benefit. Indeed, a conventional threshold principle of modern competition law regimes is that anticompetitive unilateral conduct is only prohibited to the extent that the impugned firm enjoys a certain degree of market power. Framing the case by default as anticompetitive coordination solves this conundrum.

Here, EU competition law may offer more legal ammunition and precedential authority than US antitrust law. In EU competition law, the prohibition of anticompetitive coordinated conduct enshrined in Article 101 TFEU has often been enforced against individual firm behavior, upon simple proof of a "community of interest" with other firms. Whilst this caselaw has been restricted in the Bayer judgments following an era of wide decisional expansion, ${ }^{81}$ Professors Whish and Bailey suggest that Bayer has not entirely wiped away the applicability of Article 101 TFEU, and that this issue remains foremost a question of fact. ${ }^{82}$ With this, it is plausible that the degree of linkage exhibited by the Chinese supertrust could meet the requisite legal standard demanded by EU case-law. In addition, we observe that the concept of "collective dominance" under Article 102 TFEU provides another possible avenue to capture syndicate links. ${ }^{83}$ In Italian Flat Glass, the EU's General Court noted: ${ }^{84}$ "there is nothing, in principle, to prevent two or more independent economic entities from being, on a specific market, united by such economic links that, by virtue of that fact, together they hold a dominant position vis-à-vis the other operators on the same market". In 2005, the EU Commission further noted that collective dominance could apply outside of "the existence of an agreement or of other links in law" and that a finding of collective dominance could "be based on other connecting factors and depends on an economic assessment and, in particular, on an assessment of the structure of the market in question" ${ }^{85}$

Moreover, EU competition law may provide more conceptual flexibility than US antitrust law. As is well-known, the origins of the competition law of the European Union can be traced to a German XXth century ideology called "ordo-liberalism", an intellectual current

\footnotetext{
${ }^{81}$ C-2/01 P and C-3/01 P, C-2/01 P and C-3/01 P, Bundersverband and Commission v Bayer AG, [2004] ECR I23.

${ }^{82}$ R. Whish and D. Bailey, Competition Law, Oxford University Press, 2015 at p. 115.

${ }^{83}$ N. Petit, "The Oligopoly Problem in EU Competition Law", in Research Handbook in European Competition Law, I. Liannos and D. Geradin eds., Edward Elgar, September 2013.

${ }^{84}$ GC, Case T-68/89 and T-77-78/89 Società Italiana Vetro SpA, Fabbrica Pisana SpA and PPG Vernante Pennitalia SpA v Commission, ECR [1992] II-1403, §358.

${ }^{85}$ DG Competition discussion paper on the application of Article 82 of the Treaty to exclusionary abuses, December 2005, §46. Available at http://ec.europa.eu/competition/antitrust/art82/discpaper2005.pdf
} 
which advocates absolute insulation of the economy (and regulators) from politics. ${ }^{86} \mathrm{EU}$ competition law thus embeds a philosophical rejection of any political involvement in free markets. ${ }^{87}$ Applied ordo-liberalism has led to controversial decisional initiatives in the past. An EU Commission decision concluded for instance that oral statements of the French treasury minister which sought to reassure investors in the State-owned telecom incumbent constituted an unlawful subsidy. ${ }^{88}$

This proposition may be viewed as bold, in particular by Chinese stakeholders, but it should not be. As David Stallibrass mentions, Chinese antitrust law is "substantively based on the law of the European Union". ${ }^{89}$ To some extent, the distaste for political involvement should also already underpin Chinese domestic antitrust law.

Last, let me address a possible superficial tension between the two policy proposals. If Chinese firms that belong to the syndicate are treated as a single economic unit in ex-ante merger review, they cannot (some might argue) legally be considered to be engaged in coordination in ex-post antitrust proceedings, for this requires decisional independence. But there is a justification for this differentiated standard. In ex-ante merger review, more drastic legal doctrines that minimize the risk of non-notification may be required because it is impractical to unwind industry concentration ex-post. Moreover, in EU merger control law, it is indisputable that firms that are otherwise independent can be deemed to belong to a "group" of firms for jurisdictional and substantive purposes, upon the showing of direct or indirect links between them..$^{90}$

\section{CONCLUSION}

The media has reported that, after China's Anbang took over the New York Waldorf Astoria in 2014, President Obama did not stay there during a 2015 visit to the UN, which had long been the practice, plausibly for security concerns. Anbang has deep connections to the CCP. ${ }^{91}$

But going beyond such discrete, anecdotal security concerns, the US and the EU have been idle spectators to the gobbling-up of domestic companies by Chinese acquirers. ${ }^{92}$ Forbearance has been the Western world's official doctrine vis-a-vis China. This passive policy rests on several implicit, and disputable, foundations: trust in Washington consensus-style market institutions; leap of faith in the "growth delivers democracy" narrative; and self-censorship by conflicted stakeholders - including financial industry players, law firms, consultants and academics.

\footnotetext{
${ }^{86}$ G. Amato, Antitrust and the Bounds of Power, Hart Publishing, 1997, at p. 40.

${ }^{87}$ D. Gerber, Law and Competition in Twentieth Century Europe, Oxford University Press, 1998.

${ }^{88}$ See Decision 2006/621/CE, 2 August 2004, OJ 2006, L 257/11.

${ }^{89}$ David Stallibrass, supra at p. 389.

${ }^{90}$ See Consolidated Jurisdictional Notice at $\$ 130$.

${ }^{91}$ See China's $\$ 6.5$ billion Blackstone hotel deal could ruin the secret meetings of the US elite, Quartz, March 15, 2016, Heather Timmons: "Chairman was married to the granddaughter of Deng Xiaoping, while Chen Xiaolu, the son of a prominent People's Liberation Army official is on the board of directors".

${ }^{92}$ See China's offensive in London, Foreign Affairs, April 5, 2016, Philippe Le Corre: “After Huawei signed a contract to provide equipment for the British telecommunications network, for example, intelligence officials worried that the company could pose a security threat to British infrastructure. Intelligence experts in Australia and the United States have suggested that Huawei may be linked to the Chinese state and People's Liberation Army, and in 2013, the British Parliament denounced the "facility with which the government of London has opened the door to a group whose technology apparently poses a security problem to the United Kingdom." Meanwhile, the British government has maintained its support for Huawei”.
} 
In this paper, I have advocated a more robust response which looks through the smokescreen of "Potemkin institutions" and understands that China's corporate, economic and legal governance seems to apply verbatim Lenin's precept that the entire economy should be organized as a syndicate.

This situation raises antitrust red flags, and should prompt the regulators of North America, Europe and elsewhere to take two simple, pragmatic steps under merger control and antitrust rules. ${ }^{93}$

In merger review, antitrust agencies should treat all SOEs and POEs with a Party cell as one unitary group and undertake a thorough competitive assessment of transactions on this basis. In addition, antitrust cases involving Chinese firms should be investigated on the default assumption that there is an underlying coordination scheme among them.

This is a minimal but essential price to pay if we are to maintain public confidence in the competitive, free market as the proper resource allocation system of Western society.

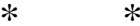

\footnotetext{
${ }^{93}$ Those adjustments are required because the operation of the Chinese supertrust is a competition problem that justifies a comprehensive review. See Li-Wen Lin and Curtis J. Milhaupt, supra at p. 708, who explain that the CCP's grip over all levers of the economy reduces competition: "The networks we describe most likely produce countervailing effects: They enhance efficiency by fostering information sharing, reducing opportunism through repeat play, providing high-powered incentives, and reducing frictions in policy implementation. But they also reduce competition and transparency, multiply agency relationships, and soften budget constraints".
} 